\title{
CITRA TOKOH UTAMA PEREMPUAN DAN NILAI PENDIDIKAN KARAKTER DALAM NOVEL CARNATION KARYA SANAZ NADYA
}

\author{
Wulan Purnama ${ }^{1}$, I'in Inayah ${ }^{2}$, Cintya Nurika Irma ${ }^{3}$ \\ PBI, FKIP, Universitas Peradaban \\ wulanpurnama819@gmail.com ${ }^{1}$, inavahata99@gmail.com², \\ Cintya_nurikairma@yahoo.co.id ${ }^{3}$
}

ABSTRAK

ABSTRACT
Karya sastra merupakan cerminan dari kehidupan manusia, salah satunya perempuan yang beragam watak sifat di dalam kesusastraan itu sendiri. Dalam sebuah karya sastra juga memiliki nilai pendidikan yang dapat diambil di dalamnya. Dalam penelitian ini menggunakan tokoh utama dalam novel Carnation,yang memiliki citra perempuan dan nilai karakter pendidikan yang cukup kuat sebagai anak remaja yang menempuh berbagai kondisi perihal kehidupannya. Penelitian ini merupakan penelitian deskriptif kualitatif. Data dalam penelitian ini berupa kutipan dan percakapan yang terdapat dalam novel Carnation karya Sanaz Nadya dan sumber data novel dan buku acuan yang berkenaan dengan penelitian. Teknik pengumpulan data dengan 2 teknik yaitu teknik baca, dan teknik catat. Teknik validitas data dalam penelitian ini dengan trianggulasi data. Tujuan dari penelitian ini adalah menjelaskan tentang citra tokoh utama dan nilai pendidikan karakter dalam novel Carnation karya Sanaz Nadya. Hasil dari penelitian ini adalah tokoh Della memiliki citra diri meliputi aspek fisik: manis, lucu, cantik, salut. Aspek psikis: penyesalan, menangis, pemarah, galak, kecemburuan, bahagia, pemalu, bijak, agresif. Ada juga citra sosial, yaitu: aspek keluarga. Nilai pendidikan dalam novel Carnation karya Sanaz Nadya meliputi: tanggung jawab, peduli sosial, disiplin, kerja keras, berbakti kepada orang tua, kasih sayang.

Kata Kunci : citra perempuan, novel Carnation, nilai pendidikan karakter

Literatur is a reflection from human existence, one ofthem is woman who has so many characteristic inteh literature it selft. Literature has also education value that we canget for our daily life. In this research the writer use the main character from carnation novel who has strong woman image and education value as a teenager, that go through varrous condition in this life. This research use qualitative descriptive study. The data in this research is a quotes and conversations taht found im carnation novel by sanaz nadya novel source and reference book relating to research. Data collection techniques with 2 techniques, namely reading techniques, and note taking techniques. The data validity 
technique in this study was data triangulation. The purpose of this research is to explain about the main characteristic and the eduaction value in the carnation novel by sanaz nadya from character. The result of this research is the main character della has phisical characteristics attractive, adorable, beautiful, admire. Psychological: regret, cry, peevish, eavy shy, wise, aggressive. There is also a ocial image: family. Education value in carnation novel: responsibe, care, work hard, blay to the parent, and love.

Keyword: woman image, novel carnation, character education value

PENDAHULUAN Setiap karya sastra yang dibuat memiliki hubungan dengan kehidupan masyarakat yang sedang terjadi sekarang yakni memuat beragam gambaran di sekitar kita, tidak jarang karya yang dihasilkan banyak menampilkan citra atau gambaran perempuan di dalamnya. Hal ini memberikan pengetahuan pada kita bahwa sosok perempuan mewarnai khasanah kesusastraan Indonesia maupun kesusastraan roman ataupun novel. Tak hilang dari sebuah pemberitaan bahwasannya tentang perempuan menjadi salah satu topik yang menarik untuk diperbincangkan oleh masyarakat dari segi keistimewaanya, keunikannya, kecerdasannya, bahkan penulis pun ketika menulis sebuah karya sastra mengenai tentang perempuan ketertarikan tersendiri bagi penulis sampai hingga si pembaca.

Novel merupakan bentuk karya sastra yang paling populer di dunia. Bentuk sastra ini paling banyak beredar, lantaran daya komunikasinya yang luas pada masyarakat. Salah satu bentuk karya sastra adalah novel. Umumnya, novel menyajikan beberapa tokoh yang saling berhubungan satu sama lainnya sehingga membentuk suatu kisah atau cerita kehidupan seseorang dengan menonjolkan watak dan sifat setiap pelakunya. Novel sebagai salah satu produk sastra memegang peranan penting di dalam memberikan berbagai kemungkinan menyikapi kehidupan seseorang yang diangkat dengan menggunakan kata-kata yang menarik.

Kehidupan yang terjadi saat ini perihal perempuan, di mana perpaduan antara kesedihan yang dirasakan perempuan. Sehingga tulisan ini dibuat untuk membuka gambaran atau citraan terhadap hidup dan kehidupan yang sedang terjadi. Citra adalah rupa dan gambaran; gambaran yang dimiliki orang banyak mengenai pribadi, perusahaan, organisasi atau produk dan juga kesan mental atau bayangan visual yang ditimbulkan oleh sebuah kata, frase, atau kalimat, dan merupakan unsur dasar yang khas dalam karya satra. Citra wanita adalah gambaran yang dimiliki orang banyak mengenai pribadi wanita. Sugihastuti membagi citra menjadi dua, yaitu citra diri dan citra sosial. Citra diri dapat dilihat dari aspek fisis dan aspek psikis. Dari aspek fisis, wanita 
mengalami hal-hal yang khas yang tidak dialami oleh pria, misalnya hanya wanita yang dapat hamil, melahirkan dan menyusui anak-anaknya. Selain itu, citra wanita juga dapat dilihat dari tinggi badan, cara berjalan, aktivitas, perilaku keseharian, dan lain-lain (Sugihastuti, 2000:87).

Pencitraan wanita secara psikis, bisa dilihat dari bagaimana rasa emosi yang dimiliki wanita tersebut, rasa penerimaan terhadap hal-hal disekitar, cinta kasih yang dimiliki, dan yang diberikan terhadap sesama atau orang lain. Ditinjau dari aspek psiskisnya, wanita juga makhluk psikologis makhluk yang berpikir, berperasaan, dan beraspirasi (Sugihastuti, 2000:95). Citra sosial wanita merupakan perwujudan dari citra wanita dalam keluarga serta citranya dalam masyarakat, seperti yang diungkapkan Sugihastuti (2000:143) citra sosial ini memiliki hubungan dengan norma-norma dan sistem nilai yang berlaku dimasyarakat, tempat wanita menjadi anggota dan berhasrat mengadakan hubungan antarmanusia.

Novel ini terbit di tahun 2017, saya mencari apakah sudah ada yang meneliti dan akhirnya saya tidak menemukannya, sehingga dapat dipastikan novel ini belum ada yang menganalisis. Sehingga membuat saya mengambil novel Carnation untuk dianalisis dan kajiannya yaitu citra perempuan dan pendidikan karakter. Untuk referensi ada dari Buku Sugihastuti dan artikel-artikel yang saya download. Namun kelemahannya dalam novel ini yaitu dalam bahasanya terlalu bertele-tele, sehingga ketika saya membaca merasa harus sabar. Diadakannya analisis dari novel ini meruapakan suatu peluang agar kita paham isi di dalam cerita ini karena memang terbilang belum ada yang menganalisis, ketika saya mencari analisis tentang buku ini sama sekali belum ada. Sehingga saya lebih semangat lagi dalam menganalisisnya. Untuk masuk publikasi pun masih bisa. Masalah dari kajian atau teori sudah banyak yang menggunakannya, sebaik mungkin saya menggunakan teori ini dibarengi dengan dua poin yaitu nilai pendidikan karakternya.

Pendidikan pada era perkembangan yang semakin maju ini, sering melupakan nilai-nilai pendidikan karakter, karena sekarang hanya mengejar nilai untuk kelulusan. Padahal aspek non akademik ini sebagai pondasi yang paling utama dalam menumbuhkan karakter anak yang sesuai dengan pendidikan karakter yang memang dititik beratkan dalam peserta didik. Nilai pendidikan karakter itu telah mengkarakter atau menjadi penanda khas kepribadian orang yang bersangkutan. Dengan demikian dapat dinyatakan bahwa karakter lebih menunjuk pada hasil dari proses penanaman nilai-nilai. Ada beberapa nilai pendidikan karakter menurut Kemendiknas yaitu: jujur, religius, toleransi, gemar membaca, peduli lingkungan, peduli sosial, rasa ingin tahu, kreatif, mandiri, bersahabat, menghargai prestasi, bertanggung jawab, kerja keras, demokratis, cinta damai, disiplin, 
atau kegiatan yang menumbuhkan kecintaan kepada bangsa, kasih sayang, berbakti kepada orang tua.

Masalah perempuan banyak dibicarakan diberbagai media masa. Masalah perempuan selalu hangat dan menarik perhatian masyarakat luas dan diungkapkan secara tuntas mulai dari kodratnya, berbagai aktivitasnya, sampai dengan peranannya. Semua itu difokuskan pada citra diri dan peranan perempuan pada berbagai aspek kehidupan. Berbagai peran yang dijalani oleh para perempuan yang merupakan makhluk sosial dan memerlukan orang lain dalam menjalankan kehidupan. Peran yang dijalani akan menampilkan citra diri yang dimiliki, dalam hal ini adalah perempuan.

Berdasarkan uraian latar belakang di atas, rumusan masalah dalam penelitian ini ialah bagaimana Citra Tokoh Utama Perempuan dan nilai karakter pendidikan Dalam Novel Carnation Karya Sanaz Nadya? Adapun tujuan dalam penelitian ini yaitu untuk mendeskripsikan dan menjelaskan Citra Tokoh Utama Perempuan dan nilai karakter pendidikan Dalam Novel Carnation Karya Sanaz Nadya.

METODE

PEMBAHASAN
Penelitian ini merupakan penelitian deskriptif dengan data berupa kutipan dan percakapan yang terdapat dalam novel. Sumber data yang digunakan adalah novel Carnation berjumlah 325 halaman, diterbitkan oleh PT Elex Media Komputindo pada tahun 2017. Teknik pengumpulan data digunakan dengan teknik membaca dan teknik mencatat. Teknik triangulasi yang digunakan dalam penelitian ini adalah tiangulasi sumber, tiangulasi teori, dan triangulasi metode. Selanjutnya, teknik analisis data merujuk pada analisis interaktif Miles dan Huberman.

Novel Carnation karya Sanaz Nadya merupakan novel yang menggambarkan tentang anak SMA yang mengalami kegundahan dalam hidupnya karena cinta pertamanya dari tokoh utama yaitu Della. Pembahasan yang dilakukan yaitu dengan fokus penelitian citra perempuan pada tokoh utama wanita pada citra diri diantaranya: aspek fisik, aspek psikis, citra sosial: aspek sosial keluarga. Dan dilakukan juga penelitian nilai pendidikan karakter pada Novel Carnation karya Sanaz Nadya.

\section{A. Citra Perempuan pada Novel Carnation karya Sanaz Nadya}

Citraan perempuan gambaran pemakaian bahasa untuk melukiskan lakuan, orang, benda atau gagasan secara deskriptif. Biasanya citraan menyarankan gambar yang nampak pada mata (batin) kita, tetapi juga menyarankan hal-hal yang merangsang panca indera. Berikut ini temuan citra diri yakni ada dalam aspek fisik dan psikis, lalu untuk citra sosial yaitu aspek keluarga yang terdapat pada novel Carnation Karya Sanaz 
Nadya.

\section{Citra Diri}

a. Pencitraan tokoh utama dalam aspek fisik pada novel Carnation karya Sanaz Nadya, antara lain:

1) Manis

Manis dalam novel yang dianalsis ini seseorang yang memiliki wajah yang menarik hati, sama halnya yang dirasakan oleh Varo memuji seseroang dalam sebuah kalimat dengan mengatakan bahwa lawan jenisnya mengutarakan orang tersebut manis.

"Lo manis banget sih Dell." Varo Spontan mengantakannya. Sedangkan Della hampir tersedak saat mendengarnya (Carnation, 2017: 24).

Aspek fisik manis yang ditunjukkan Della yang begitu manis dipandang Varo saat itu spontan saja mengatakannya. Aspek fisik yang ditemukan yaitu Della yang menjadi tokoh utama dalam novel ini memiliki fisik yang begitu manis wajahnya berseri-seri. Manis dalam artian Della memiliki wajah yang begitu manis sehingga membuat ketertarikan tersendiri bagi seorang anak laki-laki anak SMA yang bernama Varo ketika melihatnya, dan kalimat yang diucapkannya pun spontan saja tanpa ada rekayasa untuk mempersiapkan atau disengaja.

2) Lucu

Lucu dalam kalimat ini sebagai mengungkapkan perasaan tertarik dan senang bagus, melihat sebuah tindakan atau perilaku yang dilakukan oleh seseorang. Sama halnya yang diungkapkan oleh seorang anak laki-laki kepada lawan jenisnya untuk menunjukkan rasanya.

Rambut ikal gadis itu diikat asal membentuk gumpalan. Lucu. "Lucu, Dell, kalau rambut lo dicepol gitu," puji Reno (Carnation, 2017: 119).

Aspek fisik lucu di mana Reno melihat Della dengan memuji rambut yang diikatnya itu sehingga membuat orang yang melihatnya itu tertarik, sama seperti Reno yang memuji Della karena lucu. Lucunya Della terlihat dari mata Reno setelah melihat rambut ikal gadis tersebut. Della yang menggunakan ikat rambut ketika keluar bareng dengan Reno, tanpa disadari Della waktu itu Reno mengatakan hal yang membuat pujian untuk perempuan yang sedang bersamanya saat itu menarik perhatiannya karena tidak seperti biasanya rambut Della dicepol sehingga membuat pearsaan Reno tertarik kepada 
perempuan saat ini bersamanya.

3) Cantik

Cantik merupakan artian dari paras yang elok, indah untuk dipandang. Sama halnya dalam novel ini Della yang dipuji oleh sahabatnya karena parasanya yang cantik dapat perhatian dari orang lain.

"Gue iri sama lo, Della. Lo cantik, udah dibuktikan dengan anak-anak yang tertarik tiap kali lo lewat. Kalau aja lo lebih peduli dan nggak jutek sama sekitar, pasti banyak yang deketin. Pinter juga, tegas. Gue suka dan kagum saama sikap lo itu. Kalau gue mah, cuman butiran debu." (Carnation, 2017: 245).

Ketika sahabatnya Della mengungungkapkan langsung di depannya dengan kecantikannya itu Della dapat memiliki pacar atau teman cowok yang dapat dibilang lebih dari satu karena memang Della ini memiliki wajah yang cantik, siapapun yang melihatnya kan jatuh cinta dengan dibuktikan dengan anak laki-laki yang sedang melihatnya kan terus terpesona karena wajah cantik Della. Kecantikannya itu dapat membuat Della menadapatkan laki-laki yang diinginkannya begitu tanggapan dari sahabatnya.

4) Salut

Salut merupakan sebuah persaan tersanjung ketika seseorang melihat tindakan atau sebuah panadangan terhadap lawan jenisnya. Berupa pujian yang duicapkan sebagai pernyataan kagum maupupn senang.

Dalam hati Varo, ia salut pada perempuan yang mampu merawat rambut panjangnya (Carnation, 2017: 289).

Varosangat salut dengan tokoh utama dalam cerita ini, yakni Della dengan merawat rambut panjangnya yang sampai dalam hati Varo mengaguminya. Della baru SMA saja sudah pandai merawar rambutnya dengan baik, sehingga membuat orang sekitar salut dan tertarik karena Della yang begitu rajin membenahi penampilannya terutama rambut. Sebuah perasaan yang dirasakan oleh Varo kepada Della yang memuji Della dalam hatinya bahwa perempuan yang cantik itu dapat merawat rambutnya dengan baik, sampai Varo yang terpesona melihat rambut perempuan yang disukainya.

b. Pencitraan tokoh utama dalam aspek psikis pada novel Carnation karya Sanaz Nadya, antara lain:

1) Penyesalan

Penyesalan merupakan perasaan yang timbul dari diri 
seseorang tentang sebuah penyesalan atau perasaan menyeslan atas perbuatan yang telah dilakukannya selama ini, sehingga ada rasa yang sesal dalam hatinya. Sama halnya seperti dalam kutipan berikut.

Aura penyesalan kental menyelimuti Della. "Gue yang seharusnya minta maaf."Della pun ingin menangis mengingat hatinya masih dipenuhi penyesalan. Begitu banyak kalimat berlandasakan 'seandainya' muncul, bermain-main dalam pikirannya. Apalagi setelah kehadiran Varo yang membuatnya semakin mengingat Adam (Carnation, 2017: $30)$.

Aspek psikis yang terjadi pada Della sebagai peran tokoh utama dalam cerita, tentunya rasa penyesalan selama ini selalu menyelimuti pikiannya tentang Adam yang telah tiada, dan sekarang seolah-olah kembaran Adam yaitu Varo membayanginya setiap waktu. Penyesalan tentang ketidakjujurannya kepada Varo selalu membuntuti dalam pikirannya Della. Keterpojokannya ini membuatnya merasa bersalah terus menerus sehingga sampai detik ini saja Della masih merasakan perasaan yang amat menghantuinya.

2) Menangis

Menangis merupakan sebuah tindakan ketika mengalami rasa kecewa yang diluapkan untuk mengeluarkan rasa emosi dengan cara membiarkan air mata itu jatuh dan tidak bisa ditahan lagi, sama halnya pada kutipan berikut.

"Hidung gadis itu memerah, begitu pula matanya. "Jangan nangis lagi dong, Gue enggak bisa nenangin. Della yang merasakan luapan emosinya dengan menangis karena mengingat cinta pertamanya pas SMP yaitu Adam(Carnation, 2017: 143).

Della menangis karena pas ke acara di mana kenangannya dengan cinta pertamanya terulas begitu saja, tidak ada yang menginginkan hal ini terjadi. Varo yang tidak bisa nenangin Della menangis sampai hidung gadis itu memerah, serta matanya pun membengkak karena tangisan yang begitu kencang tanpa henti. Della hanya bisa menangis mengingat semuanya tentang mereka berdua pas pertama kalinya ke acara yang serba Jepang itu. Rasa kecewa mengingat hal yang sudah dilakukan dengan orang yang Della sayang kini hanya tinggal kenangan, sehingga membuatnya tidak dapat menahan rasa emosinya. 


\section{3) Pemarah}

Pemarah merupakan seseorang yang mudah marah terhadap apapun, misalnya saja ketika ada kesalahan kecil orang itu akan musah sekali marah.

Ya, sejak kecil memang Della yang paling pemarah di rumah ini. Jika kejengkelannya sudah memuncak, orangtuanya saja kesulitan meredam (Carnation, 2017: 6).

Kutipan di atas menunjukkan bahwa psikis Della yang pemarah itu sudah sejak lahir, di mana ketika rasa kejengkelannya itu sudah tidak bisa dibendung lagi pasti akan menjadi marah yang tidak bisa dikontrol bahkan orangtuanya saja tidak dapat meredam amarah anaknya itu. Tentu keluarga dalam satu rumah akan paham bagaimana sikap anaknya masing-masing, sama halnya seperti Della yang sejak kecil sudah bersama kelurganya dan tahu sifat Della yang mudah marah, apalagi ketika kejengkelannya sedang memuncak sudah tidak bisa dibaik-baikin lagi.

4) Galak

Galak merupakan sebuah tindakan yang buas atau suka melawan biacaranya dengan kasar, dapat dilihat dari sebuah perilaku yang dilakukan oleh seseorang kepada lawannya, sama halnya yang termasuk dalam kutipan berikut.

Telapak tangan Della mampir di wajah Varo, mendorongnya menjauh. "Usah banyak bacot. Jam lima tepat kalau enggak nyampe tujuan, gue langsung balik." "galak sekali mbak!" protes Varo (Carnation, 2017: 40).

Aspek psikis Della yang memainkan tangannya mendorong laki-laki yang fisiknya mirip cinta pertamanya itu dengan kasar, mencoba menjauhkan badan Varo dari Della karena risih sehingga Della mengatakan dengan galak kalau Varo tidak usah banyak bicara karena jam menunjukkan pukul lima, Della yang mengancam jika tidak tepat waktu sampai tujuan dirinya akan pulang sendirian. Dari percakapan yang ditemukan terlihat Della berkata kasar seperti usah banyak bacot yang membuatnya sedikit galak kepada Varo yang harus sesegera mungkin sampai ke tempat tujuan yang akan dikunjungi oleh mereka.

5) Kecemburuan

Kecemburuan merupakan rasa iri atau sirik seseorang kepada orang yang tidak diuskainya atau lawan yang ada di 
depannya.

Aneh. Satu kaya yang bisa mendeskripsikan suasana hati Della saat ini. Sejak melihat Varo mempersilahkan Lianna masuk ke dalam mobilnya kemarin, ada perasaan yang mengganjal (Carnation, 2017: 218).

Rasa kecemburuan Della kepada Lianna ketika Varo yang selalu bareng kemana-mana dengan teman perempuannya itu, sampai dengan untuk naik mobil saja Varo mempersilahkan Lianna diperlakukan seperti pacarnya. Della yang melihatnya merasa ada yang mengganjal dengan perlakuan Varo yang beda kepada Lianna, dan Della merasa hati Della beda seperti rasa tidak terima dengan apa yang dilihatnya. Rasa sedang Della rasakan ini merupakan iri atau kecemburuan terhadap Lianna yang memang dilihatnya ketika saat bersama Varo orang yang mulai disukainya.

6) Bahagia

Bahagia merupakan keadaan seseorang yang sedang merasakan senang dan tentram dalam hidupnya. Seperti pada kutipan berikut.

Senyum semringah yang ditahan Della sejak bangun tidur kini tak tertahankan karena ia melihat anggota keluarganya menghampirinya pelan-pelan sambil bersenandung bersama (Carnation, 2017: 257).

Kutipan di atas menunjukkan bahwa psikis Della yang merasakan bahagia karena dengan perhatian yang diberikan orangtuanya, adik, dan kakaknya saat merayakan ulang tahunya Della berkumpul menyanyikan lagu ulang tahun untuknya. Rasa yang tidak akan pernah tergantikan dengan apapun sebab keluarga adalah harta yang paling berharga bagi Della. Tentu perasaan yang Della rasakan adalah senang yang tidak adapat ditukar dengan apapun, hal yang seperti ini adalah momen baginya. Kebagahagiaan yang amat dirasakannya sehingga tak mampu melakukan hal apapun lagi ketika berada di lingkungan keluarga yang sangat menyayanginya.

7) Pemalu

Pemalu merupakan sifat seseorang dengan mudah merasa malu ketika pada situasi yang tidak membuatnya nyaman, seperti kutipan berikut.

Della bergidik mendengar penuturan cowok itu. Seumur hidup, ia baru pertama kali menemukan orang seberani Varo 
yang mengumbar gombalan secara terang-terangan pada orang yang baru dikenalnya beberapa hari (Carnation, 2017: 23).

Della pemalu yaitu saat Varo laki-laki yang mirip fisiknya dengan Adam yang merupakan cinta pertamanya mengungkapkan persaannya yang dikemas dengan gombalangombalan yang diberikan kepada Della orang yang baru dikenalnya itu. Rasa Della yang tak karuan bertemu dengan orang baru memeiliki perasaan yang tidak enak atau risih dengan apa yang diungkapkan oleh Varo itu. Della yang merasa ada kejanggalan dalam hatinya ya rasa malu itu mulai dirasakan tak karuan dibuatnya, ada cowok yang beraniberaninya mengatakan hal yang tidak semestinya untuk diungkapkan malah diungkapkan secara terang-terangan oleh anak laki-laki bernama Varo.

8) Bijak

Bijak merupakan suatu sikap atau tindakan yang dilakukan oleh seseorang yang selalu menggunakan sebagai haknya dalam bertindak, dalam artian pandai berbicara dapat menginsiprasi orang lain atau usulannya dapat diterima. Ketika Della menemui Varo di rumahnya untuk menjenguk karena sakit yang dideritanya membuat dirinya tidak dapat mengikuti pembelajaran pada hari itu. Della yang mencoba menenangkan dengan kata-kata untuk mengembalikan semangat Varo dengan memberi nasihat, Della yang memang tadinya dapat disebuat dengan orang yang tidak gampang akrab dengan laki-laki apalagi anak laki-laki ini miirip dengan cinta pertamanya tetapi tam mambuat Della terenyuh untuk menjenguk.

"Jangan berlebihan. Setiap manusia itu beruntung dalam kehidupannya karena dapat menikmati keindahan dunia ini. Enggak perlu menunggu meninggal untuk tahu siapa yang menyayangi lo. Sebenarnya lo udah menemukan orang yang mengenang dan menghargai tiap embuasan napas lo. Mereka adalah orangtua." ucap Della kepada Varo (Carnation, 2017: 101).

Della memberikan sedikit motivasi bahwasannya kita di dunia ini tidak boleh mengeluh harus menikmati keindahannya, tidak perlu menunggu meninggal dulu baru tahu siapa yang benar-benar perduli dengan kita. Orangtua merupakan orang yang paling berjasa dan perduli kepada kita sebagai anaknya. Hal ini lah yang membuat Della mengucapkan kata bijak kepada Varo supaya anak laki-laki itu sadar bahwa kita hanya perlu memikirkan yang indah, 
jangan sampai pikiran kita dipenuhi dengan hal yang aneh dan tidak masuk akal seperti mengeluh dan berpikir tidak ada yang mau memperdulikan kehadirannya,

9) Agresif

Agresif merupakan sifat seseorang yang memiliki nafsu yang berlebihan atau suatu tindakan melebihi batas, sebuah kecenderungan yang dialami oleh seseorang terhadap suatu hal, seperti kutipan berikut.

Tanpa disadari, tangan Della terangkat berkehendak menyentuh pipi pemuda yang sejatinya baru ditemuainya kali ini. Tetapi tangannya, kembali ke sisi tubuh ketika jantungnya berdenyut nyeri karena sadar lelaki ini bukan orang yang ada dalam benaknya (Carnation, 2017: 9).

Della ini agresif di mana dirinya dengan tanpa sadar langsung tangannya hendak menyentuh pipi lali-laki yang mirip fisiknya dengan cinta pertamanya padahal Della baru menemuinya kali ini, rasa yang tidak karuan ini menyita perhatian Della dengan tanpa paksaan tetapi keagresifannya ini membuatnya malu akhirnya rasa nyeri diakibatkan karena rasa tersadar dalam benaknya bahwa laki-laki ini bukan Adam tetapi orang lain.

\section{Citra Sosial}

Citra sosial ini memiliki hubungan dengan norma-norma dan sistem nilai yang berlaku dimasyarakat, tempat wanita menjadi anggota dan berhasrat mengadakan hubungan antarmanusia. Pencitraan tokoh utama dalam aspek keluarga pada novel Carnation karya Sanaz Nadya.

Senyum semringah yang ditahan Della sejak bangun tidur kini tak tertahankan karena ia melihat anggota keluarganya menghampirinya pelan-pelan sambil bersenandung bersama (Carnation, 2017: 157).

Aspek keluarga dari citra sosial telihat ketika Della Ulang tahun keluarga berkumpul memberikan kejutan kepada Della dengan menyenayikan lagu selamat ulang tahun yang dinyanyikan secara bersama ketika Della keluar dari kamarnya, rasa bahagia, sedih dan terharu membuat Della bersyukur memiliki keluarga yang amat sangat mencintainya apalagi keluarga besarnya itu selalu ada dengan Della ketika suka maupun duka, rasa yang tak pernah tergantikan dengan apapun. Terlihat dari Della aspek kelurga itu mempunyai rasa peduli dengan keluarga apalagi menyangkut dengan rasa yang ada pada diri Della. 


\section{B. Nilai Pendidikan Karakter pada Novel Carnation karya Sanaz Nadya}

Berikut ini temuan nilai-nilai pendidikan karakter yang terdapat pada novel Carnation Karya Sanaz Nadya, baik yang berasal dari percakapan antartokoh maupun narasi pengarang.

1. Tanggung Jawab

Tanggung jawab merupakan sikap dan perilaku seseorang untuk melaksanakan tugas dan kewajibannya yang seharusnya dia lakukan, terhadap diri sendiri, masyarakat, lingkungan (alam, sosial, dan budaya), negara dan Tuhan Yang Maha Esa. Rasa tanggung jawab yang dimiliki oleh Della yang dipaparkan langsung oleh penulis menggambarkan tokoh Della yang mempunyai rasa tnaggung jawab dengan dibuktikan dengan cara Della yang bertanggung jawab untuk mengambil tugas dari $\mathrm{Bu}$ Winda yang ketingglan padahal hari itu juga harus dibagikan dan dikerjakan oleh siswa, rasa tanggung jawab Della ini membuat Varo sebagai ketua kelas ikut bertanggung jawab pula dengan mengantar untuk mengambil tugas yang ketinggalan di rumahnya Della.

Tepat ketika mereka melihat Pak Bima berjalan bersama beberapa guru lain, Varo berhenti melangkah. Memperhatikan punggung gadis itu yang setengah membungkuk di hadapan Pak Bima sembari menjelaskan situasi dan kondisi yang dihadapinya. Della yang penuh tanggung jawab sedang berusaha memperbaiki kesalahannya (Carnation, 2017: 83).

Penulis mengajarkan pentingnya rasa tanggung jawab, di mana ketika sudah diamanati oleh seseorang harus ditetapi, jangan mnghindar dan berusaha untuk tetap menjalankan apa yang sudah diperintahkan kepada kita. Karena kepercayaan seseorang kepada kita harus dijaga, apalagi tanggung jawab kita sebagai orang yang mampu untuk melakukan hal yang sudah semestinya dipertanggung jawabkan di dunia mapun di akhirat nanti.

2. Peduli Sosial

Manusia pada dasarnya merupakan makhluk sosial yang tidak dapat hidup sendiri dan membutuhkan orang lain. Oleh karena itu, manusia diharapkan saling membantu dan bermanfaat buat orang lain. Manusia saling menghormati, mengasihi dan peduli terhadap lingkungan sekitar.

Della dengan tergesa membeli es batu dan mengompres lengan kemerahan Varo dengan lap basah tersebut 
(Carnation, 2017: 241).

Rasa peduli terhadap sesama, saling membantu satu sama lain ketika temannya dalam keadaan susah ataupun ada hal yang tidak mengenakan seperti kecelakaan atau sebagainya kita sebagai teman harus menolongnya, sama halnya dengan Della ynag peduli dengan Varo sebagai teman sekolahnya di mana ketika Varo terkena kuah panas yang tertumpah dari mangkuk Della langsung dengan sigap tanpa pikir panjang membeli es batu ke warung untuk mengompres lengan Varo yang kemerahan akibat tumpahan kuah panas saat di kantin.

\section{Disiplin}

Sikap disiplin merupakan perasaan taat dan patuh terhadap nilai-nilai yang dipercaya merupakan tanggung jawabnya. Pendisiplinan adalah usaha untuk menanmkan nilai ataupun pemaksaan agar subjek memiliki kemampuan untuk menaati sebuah peraturan. Della yang enggan untuk terlambat masuk sekolah, dengan berbagai cara menyususri gang-gang yang ada di jalan agar dapat ke sekolah tepat waktu. Rasa yang ada dalam diri Della ini disiplin tidak mau telat dan tepat waktu.

Meski tidak ada senior galak yang akan menghukum karena keterlambatan ikut orientasi, tetap saja Della paling anti dengan telat kecuali ada urusan yang sangat mendadak dan penting (Carnation, 2017: 8).

Sikap disiplin tepat waktu juga perlu dipatrikan khusunya saat jam masuk sekolah karena ketika terlambat pasti ada hukumannya, oleh sebab itu disiplin itu sangat penting untuk diri sendir apalagi bagi kehidupan kita. Sama halnya dengan Della dia berusaha agar tidak telat, adapun telat karena acara penting atau urusan yang tiba-tiba dengan mendadak, bukan disengaja atau direncakan karena dampaknya akan merugikan diri kita sendiri. Sukses berawal dari kedisiplinan dan kegigihan kita dalam bertindak.

\section{Kerja Keras}

Kerja keras yaitu perilaku yang menunjukkan upaya sungguh-sungguh dalam mengatasi berbagai hambatan belajar dan tugas, serta menyelesaikan tugas dengan sebaikbaiknya. Seseorang yang bekerja keras dan bersungguhsungguh, nantinya akan dapat mencapai suatu hasil yang memuaskan. Kerja keras yang ada pada Papanya Varo yang bekerja keras untuk menghidupi anak semata wayangnya, karena memang ayangnya Varo ini menjadi tulang punggung sekaligus ibu yang harus membimbing anaknya yang sekarang sudah beranjak remaja setiap hari Papanya Varo 
pergi kerja sebelum matahari terbit dan pulang ke rumah setelah matahari terbenam apalagi sampai larut malam karena memang pekerjaannya yang sangat banyak di kantornya.

Aria lebih senang memakai jasa sopir untuk mengantar jemput diirnya dan Varo. Sebelum matahari terbit, Idan sudah siap mengantar Atria ke kantor sementara anaknya masih terlelap. Atria jarang melihat matahari terbit di rumah saat hari kerja karena berangkat sebelum matahari muncul dan sampai rumah selepas isya (Carnation, 2017: 168).

Guna menghidupi keluarga harus dengan kerja keras berangkat pagi sebelum matahari terbit dan pulangnya sesuadah matahari terbenam. Seseorang yang bekerja keras untuk menghidupi keluarganya tanpa ada rasa menyerah untuk membuat keluarga bahagia. Seseorang yang mempunyai keinginan untuk sesuatu semisal membahagiakan orang yang kita sayang harus dengan kerja keras dan perjuangan yang amat besar, dan banyak pengorbanan yang harus dilalui.

5. Berbakti kepada orangtua

Berbakti kepada orang tua mencerminkan nilai pendidikan karakter pertama, yakni religius (sikap dan perilaku yang patuh dalam melaksanakan ajaran agama yang dianutnya, toleran terhadap pelaksanaan ibadah agama lain, dan hidup rukun dengan pemeluk agama lain). Berbakti kepada orang tua merupakan suatu kewajiban, kebajikan dan perilaku yang sangat mulia. Varo adalah tokoh yang berbakti kepada orang tuanya dengan cara mengahargai papanya ketika datang dirinya langsung duduk dan menyalami ayahnya dengan sopan serta menanyakan kepada papanya sudah makan atau belum, jika belum Varo pun akan menemani papanya untuk makan bersama.

Mendengar nada kesal ayahnya, Varo duduk dan salim dengan sopan. "Varo ngantuk Pa. Kecapekan tadi pas di sekolah. Jadi, pas nyampe rumah langsung tidur. Papa udah makan? Kalau belum nanti Varo temenin makam." (Carnation, 2017: 170).

Salah satu cara berbakti kepada orang tua semisal dengan cara ketika bertemu harus menyalami dengan sopan dan menanyakan kabar untuk hari ini, serta menanyakan sudah makan atau belum. Sebaiknya jika orang tua berada dengan kita, dengan perilaku yang sopan orangtua akan senang dengan kita. Menghormati orangtua itu wajib, karena kita sebagai anak harus menjaga kesopanan dan berbakti dengan cara apapun untuk orang tua selagi itu masih dalam cara yang 
positif tentunya tidak menyimpang.

6. Kasih sayang

Kasih sayang adalah kebutuhan dasar manusia dalam mengembangkan daya emosinya. Rasa kasih sayang ditunjukkan bukan dari keluarga saja tetapi bisa kepada sesama. Rasa kasih sayang bisa didapat dari persahabatan dan pertemanan. Hal ini juga merupakan salah satu bentuk dari sikap peduli sesama. Apabila memiliki seorang relasi yang hangat dan menggembirakan dengan sahabat bisa membuat kita merasakan kasih sayang yang sama seperti kasih sayang yang diberikan oleh keluarga di rumah. Novel ini mempunyai cerita tentang rasa kasih sayang Aria sebagai Papanya Varo ini sangat terlihat dari percakpan yang ditunjukkan dari tindakannya mengusap puncak kepala Varo sebagai anaknya dengan kasih sayang seorang ayah. Ditambah lagi dengan cerita yang diungkapkan oleh ayahnya Varo tentang anaknya itu waktu kecil sangat manja, apa-apa selalu dengan ayahnya.

"Emang Varo dulu pendiem gitu, Pa?" tanyanya bingung. "Iya." Aria mengusap puncak kepala anaknya dengan sayang, "Waktu masuk TK kamu benar-benar tenang. Setelah kepergian Mama, barulah kamu sering sekali mengajak Papa main, merengek minta diajak ke sana kemari. Kalau keinginannya tidak terpenuhi, bisan ngambek berhari-hari. Kamu jadi bergantung sama Papa." (Carnation, 2017: 171).

Rasa kasih sayang orang tua itu sepanjang hayat, apalagi dalam cerita ini ayahnya Varo seorang papa yang mandiri mampu mengajarkan anaknya untuk tumbuh dengan baik. Memberikan kasih sayang yang lebih seperti mengusap puncak kepala Varo dengan sayang. Menceritakan masa kecilnya yang selalu ingin bersamanya. Orang tua akan selalu bersama kita, ketika kita sedih orangtua pasti akan selalu memberikan dukungan dan motivasi kepada anaknya agar kita sebagai anak bangkit dari masalah ataupun yang membuat kita lemah. Orang tua apalagi ayah sebagai tulang punggung keluarga akan bersama kita dalam proses perjalanan menempuh segala rintangan kehidupan. diri diantaranya: aspek fisik (1) manis, (2) lucu, (3)cantik, (4) salut/menarik. Tokoh utama dalam novel Carnation ini Della yang memiliki aspek fisik yang dapat dibaca oleh pembaca dan dipaparkan oleh penulis terhadap Della yang memperlihatkan keindahan rambutnya sebagai teman, sebagai wakil ketua di kelas juga dapat dilihat dari segi sahabat. Aspek psikis meliputi (1) penyesalan, (2) menangis, (3) pemarah, (4) galak, (5) 
kecemburuan, (6) bahagia (7) pemalu, (8) bijak (9) agresif. Citra sosial yang ditemukan berkaitan tentang aspek sosial keluarga. Aspek yang ditemukan dalam novel ini hanya aspek sosial karena rasa sosial atau kemasyarakatan peduli terhadap keluarga, keluarga yang menjadi peeran penting untuk Della. Dalam penelitian ini juga ditemukan enam nilai-nilai pendidikan karakter dalam novel Carnation, meliputi (1) tanggung jawab, (2) peduli sosial, (3) disiplin, (4) kerja keras (5) berbakti pada orang tua, (6) kasih sayang. Nilan karakter yaitu nilai yang terdapat dalam novel mencerminkan suatu tindakan atau perilaku yang ditulis oleh pengarang terhadap novel agar mempunyai kemanfaatan bagi pembaca.

\section{DAFTAR PUSTAKA}

Andika Putri. 2017. Citra Tokoh Utama Perempuan Dalam Novel Padang Bulan Karya Andrea Hirata Dan Kelayakannya Sebagai Bahan Ajar Sastra di Sekolah Menengah Atas (SMA). Universitas: Universitas Bandar Lampung.

Anthonia Paula Hutri Mbulu. 2017. Citra Perempuan Dalam Novel Suti Karya Sapardi Djoko Damono: Kajian Kritik Sastra Feminisme.

Irma, Cintya Nurika. 2018. Nilai-Nilai Pendidikan Karakter Dalam Novel Ibuk Karya Iwan Setyawan. Universitas: Universitas Peradaban.

Endaswara. 2013. Metodelogi Penelitian Sastra Epistemologi, Model, Teori dan Aplikasi. Yogyakarta: CAPS (Center for Academic Publishing Service)

Isminarti, Rosita. 2010. Citra Perempuan dalam Novel Kesempatan Kedua Karya Jusra Chandra, Tinjaun Feminisme Sastra. Universitas: muhammadiyah Surakarta.

Marlina Susanti1, Hamidin2, M. Ismail Nst. 2013. Nilai-Nilai Pendidikan
Karakter Dalam Novel NazarNazar Jiwa Karya Budi Sulistyo En-Nafi'. Universitas: Universitas Negeri Padang.

Meleong, Lexy. 2014. Metodelogi Penelitian kualitatif. Bandung: PT Remaja Rosdakarya.

Nadya, Sanaz. 2017. Carnation. Jakarta: PT Elex Media Komputindo

Noni Febriana, Harris Effendi Thahar, Ermanto. 2014. Nilai-Nilai Pendidikan Karakter Dalam Novel Rantau Satu Muara Karya Ahmad Fuadi: Tinjauan Sosiologi Sastra. Universitas: Universitas Negeri Padang.

Nurgiyantoro, Burhan. 2007. Teori Pengkajian Fiksi. Gadjah Mada: University Press.

Pujiwijayanti, Dian. 2013. Citra Tokoh Utama Wanita Dalam Roman Cocak Nguntal Elo Karya Suprapta Brata. Universitas: Universitas Negeri Yogyakarta.

Ratna, Yoman Kutha. 2012. Teori Metode dan Teknik penelitian sastra. Yogyakarta: pustaka pelajar. 
Samani, Muchlas dan Hariyanto. 2011. Pendidikan Karakter. Bandung: PT. Remaja Rosdakarya.

Sugihastuti dan Suharto. 2010. Kritik sastra feminisme, teori dan aplikasinya. Yogyakarta: pustaka pelajar.

Sugihastuti. 2000. Wanita Di Mata Wanita, Persektif Sajak-Sajak Teory Heraty. Penerbit Nuansa.

Winda Dewi Pusvita. 2017. Nilai-Nilai Pendidikan Karakter Pada Novel Ayah Karya Andrea Hirata. MTsNU 10 Penawaja Tegal: Leksema Vol 2 No 1 Januari-Juni. 